\title{
MESEFELDOLGOZÁS - NEUROPSZICHOLÓGIAI INTERVENCIÓS LEHETŐSÉGEK
}

\section{PATAKY ILONA}

Országos Pszichiátriai és Neurológiai Intézet, Agyérbetegségek Országos Központja E-mail: pataky@opni.hu

\begin{abstract}
A klinikai neuropszichológus számára kínál gyakorlati tapasztalatokat a cikk. A terápiás szemléletü neuropszichológiai vizsgálat az organikus agysérült betegek komplex pszichológiai kezelésének alapját képezi, amely irányultságában inkább a pszichoterápia és nem a hagyományos orvoslás nyomdokain próbál haladni. Közismert, gazdagon illusztrált meséket használtunk 9 jobbkezes afáziás stroke betegnél (6 férfi - 3 nö, 7 fluens és 2 nonfluens) a beszédtevékenység aktivizálására. A mesefeldolgozást minden betegnél öt ülésben végeztük. Az afázia klasszifikációját a Western afáziateszt alapján végeztük. A történet elmondását, a beszédet magnetofonon rögzítettük és elemeztük. A terápiás helyzet lehetőséget nyújtott a betegeknek megfelelóen szelektálni a rendelkezésre álló információból, a neuropszichológusnak pedig megfigyelni azt, hogy milyen megküzdési stratégiákat alkalmaz/részesít elönyben a beteg.
\end{abstract}

Kulcsszavak: kognitíu térképezés, -terápia, -stílus, -rehabilitáció, serkentés, gátlás, transzfer, segitö technikák, megküzdési stratégiák

\section{BEVEZETŐ}

Napjainkban egyre több közleményben tűnik fel a neuropszichológia, fóként az idegtudományok területén működő, a differenciáldiagnosztikai törekvéseket hordozó munkacsoportok tollából, a korábbi diagnosztikai kategóriákat alapjaiban megváltoztató munkák (Freund, 1999; KÉRI, JANKA, 1999). Másik fontos területe a modern neuropszichológiának a gyógyszergyárak által finanszírozott, főként

Ezúton szeretném kifejezni köszönetem dr. É. Kiss Katalin nyelvész segítségéért, aki a pályázatot vezette, s a táblázatokban szereplő Western afáziateszt fölvételét, kiértékelését végezte. A kutatás a Soros Alapítvány támogatásával folyt. 
számítógépes vizsgálati battériák (PUHR, 1999) szerkesztése, alkalmazása, amelyek feladata a célfunkció precíz vizsgálatán túl az állapotváltozások regisztrálása a vegyület hatékonyságának bizonyítása érdekében. Harmadik, egyre népszerủbb téma a különböző etiológiájú demenciák neuropszichológiai differenciáldiagnózisa (Wesnes, Hildebrand, MOHr, 1999). Épp így népszerűek a számítógépes rehabilitációs programok (PUHR, 1999), amelyek a sérült kognitív funkciók reorganizációját célzottan választott számítógépes feladatsorok igénybevételével gyakorol(tat)ják be. Sorolhatnánk tovább azokat az argumentumokat, amelyek a klinikai neuropszichológia népszerűségi hullámának növekedésével együtt azt is jelzik, hogy - mint oly sokszor a pszichológia történetében - azzal a jelenséggel állunk szemben, hogy a kognitivizmus jegyében mindent erre a divatos kaptafára kívánunk húzni. Eközben a klinikai neuropszichológiát a pszichometria szintjére degradáljuk, olyan eszközök birtokába kívánunk jutni, amelyekkel különösebb értelmi erőfeszítés nélkül számszerűsíthető eredmények halmazához juthatunk, amelyekből spekulációval kívánunk a háttérben zajló idegrendszeri történések mélyére látni. Különösen igaz ez, ha a neuroradiológus vagy ultrahangos munkacsoport tagjaival együttműködve hipotézisünkhöz meggyőző érveket találunk.

Az ilyen törekvések nyomán persze korszakalkotó eredmények születtek: ma az afázia klasszifikációja új alapokon nyugszik, s néhány gyors, egyszerủ feladat nyomán maga a neurológus képes eldönteni az afázia típusát, s összhangba hozni azt a sérülés lokalizációjával. A szkizofrénia kutatásában is a műszeres és a neuropszichológiai vizsgálatok együttese mérföldkövet jelentett a kognitív funkciók alakulásának idegrendszeri hátterére vonatkozóan (KÉRI, JANKA, 1999). Mi dolga marad akkor ebben a bonyolult kutatási folyamatban a logopédusnak, nyelvésznek, netán a klinikai neuropszichológusnak?

Mintha újra élnénk a lokalizációs tanok korszakát, amikor azt keresték a neurológusok, neuropatológusok, hogy az adott neurológiai tünetegyüttes hátterében milyen idegsejtek pusztulása húzódik meg. Mintegy 100 évvel később a funkcionális térképet szeretnénk megrajzolni egy-egy pszichés működés megvalósítására vonatkozóan. A gondolatmenet azonban ugyanaz. A pszichológiai jelenségeket a létrejöttükhöz elengedhetetlen idegi múködésszerveződésben kívánjuk megragadni. Ebben a filozófiai aspektust félretéve az a kiinduló hipotézis érhető tetten az egyes egyéneknél, hogy azonos módon alakulnak ki - járatódnak be - az egyes pszichés funkciók fejlődése során az idegpályák, hogy ugyanazon sejtláncolat aktivitása révén valósul meg például a beszéd, olvasás, írás stb. Az ettől való eltérés már deviáns pszichés fejlődést alapoz meg, a különböző lelki eredetű megbetegedések forrása lehet. Akkor hogyan érthető, hogy míg egyesek a dallamok memorizálásában erőfeszítés nélkül érnek el eredményt, mások a téri viszonyok reprodukálásában élveznek összehasonlíthatatlan előnyt, s vannak, akik számára a számok megjegyzése nem jelent egyáltalán semmilyen problémát stb.?

A nemzetközi szakirodalmat áttekintve sok kifejezetten jó, a kognitív funkciók térképezésére alkalmas battéria áll rendelkezésre, hogy az egyes funkciódeficitek körvonalazását szolgáló eljárások gazdagságáról már ne is tegyünk említést 
(LEZAK, 1995). Ma már nem csak a minőségelemzés követelményeinek tesznek ezek a feladatsorok eleget, de alkalmasak arra is, hogy mennyiségi mutatókban fejezzék ki a neuropszichológiai szempontból értékelhető változásokat. A képalkotó eljárások modernizálódásával egyre nagyobb számban készülnek olyan vizsgálatok, amelyekben az agyi vérátáramlás változását különböző kognitív tesztek végzése közben követik. Számítógép-vezérelt programcsomagok kerültek bevezetésre nemcsak a neuropszichológiai diagnosztikában, de a terápiában is. Mindezek a megközelítések inkább a medicinális szemléletmódot tükrözik: a tüneteket keresik, megvizsgálják, mi a baj - diagnózist állítanak föl -, és a gyógyítás során alkalmazzák a konszenzus alapján kidolgozott eljárások közül a megfelelőt. Anélkül, hogy a fenti terápiás gyakorlat érvényességét és eredményességét kétségbe kívánnánk vonni, óhatatlanul fölmerül a kérdés, amikor a megismerőtevékenységgel annak zavaraival - foglalkozunk: vajon ez minden, amit tehetünk? Elég-e, hogy gyakorlatokat adunk a betegnek, amelyekkel a sérült funkciók a tudományos közleményekben leírt sémák szerint rehabilitálhatók?

Jelen kutatás indíttatását éppen ezek a gondolatok adták. Olyan eszköz kimunkálása volt a cél, amely a súlyos kognitív deficittel - aktuálisan afáziával küszködő beteg számára a saját adekvát aktivitásnöveléséhez nyújt kereteket, és ezzel a rehabilitáció esélyét általában javítja (PATAKY, 1998). Másképp fogalmazva, a beteg saját megküzdő stratégiáit (coping strategy) mozgósítja az exponált problémahelyzetben. Olyan meglévő vagy korábban megvolt munkamódokat hoz felszínre, amelyek a deficitek kezelésében hatékonyak lehetnek. Elengedhetetlen ebben a tevékenységben, hogy a beteg képes legyen szembenézni a központi idegrendszer károsodása következtében föllépő kognitív deficitjeivel, s azokat a maguk valóságában észlelje (betegségbelátás, betegségtudat problémája). Meggyőzően demonstrálni kell, hogy azok az erőfeszítések, amelyeket tesz, a kívánt cél irányában mozdítják el produkcióját. A klinikai neuropszichológia viszonylag rövid történetében a megjelölt kritériumoknak megfelelő feladatra nem sikerült bukkanni (BACH, Rita, 1990; Christensen, UzZel, 1994; Gummow, Gregory, MacNamara, 1990; Kapur, 1991; Martin, Alberdi, Sacho Reiger, 1993; NeWCOMBe, 1985; WAHRBORG, 1988). Pontosabban mondva nem annyira az eszköz hiányáról kell beszélni - hiszen közismert mesék földolgozásáról jelentek meg tanulmányok -, hanem ezek felhasználásmódjának újszerűségéről.

A mesefeldolgozás a maga komplexitásában azzal a reménnyel is kecsegtetett, hogy nemcsak terápiás célokra ideális, de diagnosztikus vonatkozásban is nyújt adatokat. Felnőtt korban, az idegrendszer érésének befejeződésével, a pályák kialakulásával egy történet fölidézése, elmondása a megfelelő kérgi központok együttműködése révén valósul meg. Ehhez képest jóval nagyobb és egészen más, korábban aktív központi idegrendszeri területek mozgósítódnak a - gyermekkorban megismert - mesék fölidéz(őd)ése során (LuRIJA, 1975). Az afáziás betegek számára olyan eszközt kerestünk, amely működésbe hozza a mesehallgatás-elmondásban hajdanvolt aktív idegrendszeri területeket, mindezt a beteg saját aktivitása révén. 


\section{MÓDSZER}

A közismert mesék közül választottuk ki a módszer segédanyagát. Szín- és formagazdag, jellegzetes ábrák illusztrálták az idegen nyelven - angolul - rövid szövegrészt tartalmazó meséket. A szövegben latin eredetű, de magyar nyelven ismert fragmentumok is segíthették a földolgozást. Tartalmazott például versikét a mese, amelyre az angol szöveg jól elkülönülő utalást is tett. Olyan eszközt igyekeztünk tehát találni, amely alkalmat kínál a képi, a formai, a szövegbeli információ fölhasználására, s a választást a betegre bízza. Ez a választási szabadság lehetővé teszi, hogy az idegen nyelvű szövegben fölfedezzen nemzetközi kifejezéseket anélkül, hogy kényszerülne végigolvasni az egész mesét. Magyar nyelvú szövegnél az eszköznek eme implicit üzenete - más utak keresése - elveszne, s mi sem különböztetné meg a szokvány színes képeskönyvek olvasásának feladatától. Feltételezésünk szerint ez a módszer a fáziás zavarokban nem érintett területek mobilizálásával, indirekt módon, a beteg spontán tevékenységének aktivizálása révén hat, s így a feladatban mutatkozó teljesítmény alakulása prognosztikai értékủ lehet a beszédzavarok kezelésében. Másrészről a feladat komplexitása azt is megengedi, hogy az információfeldolgozás különböző jellegű zavara esetén mintául szolgáljon a fölhasználható csatornák kompenzáló aktivitásának kibontakoztatására. Másképpen fogalmazva - az ebben a feladatban mutatkozó teljesítmény a beteg spontán kereső-aktivitását tükrözi, és így nemcsak a fáziás zavarok, de általában a kognitív rehabilitáció prognózisában is értékes adatokkal szolgálhat.

A következő meséket alkalmaztuk: Pinocchio, Hamupipöke, Hófehérke, Gulliver Lilliputban, Hetet egy csapásra, Arasznyi emberkék, A kis hableány, Aladdin és a csodalámpás, Ali baba és a negyven rabló, Heidi, Szamárfülü Midas király, Az erdöszéli házikó, A kis ólomkatona.

Komplex afázia-kezelés keretében összesen 9 afáziás beteggel készítettük el magnófelvétel fölhasználásával a szövegfeldolgozás jegyzőkönyvét. Minden beteggel öt alkalommal, kórházon kívül történtek az egyenként 60 perces foglalkozások, s mindenki öt mesét dolgozott fel.

A komplex terápiás munka első szakaszában zajlott le a szövegfeldolgozás.

Időt szakítottunk annak megbeszélésére, hogy az idegen nyelv ismerete nem szükséges a feladatban való részvételhez. Alkalma volt meggyőződni a betegnek arról, hogy konstruálható történet pusztán a színes illusztrációk fölhasználásával, de - ahogy együtt átlapoztuk a mesét - egy-egy idegen szónál maga a beteg is jelezte, hogy ismeri. A családdal való előzetes megbeszélés nyomán választottuk ki az adott betegnél exponált meséket, hogy biztosan ismerősek legyenek. A beteg tetszőleges ideig tanulmányozhatta a rendelkezésre álló információt, maga jelezte a vizsgálat vezetőjének, hogy elkészült a földolgozással; átlagban 10-15 percet szántak erre - fóként a képek áttekintésére - a betegek. Az egyes üléseken kérdésekkel lendítettük tovább a történet folyamatosságát, arra törekedtünk, hogy a beteg a figyelmét, aktivitását a mese által kínált keretek között tartsa, s a kétségeinek eloszlatásához a rendelkezésre álló információk közül válasszon támpontot. Törekedtünk a célravezető segítő stratégiákat tetten érni és megerősíteni. Az elbe- 
szélés végén visszatértünk a kritikus pontokra, kiegészítve a hiányzó láncszemeket, illetve az elmondás folyamatában fölbukkanó szavakat, kifejezéseket megkíséreltük újból, szándékosan előhívni. Ehhez a mese végén található színes illusztrációkat használtuk föl, amelyek a főbb szereplőket, a fontos, jelentőséggel bíró tárgyakat emelték ki (megnevezési feladat). Ez a helyzet egyben alkalmat adott arra is, hogy ellenőrizzük, vajon az indirekt eszközökkel előhívott szavak direkt módszerrel könnyebben aktiválhatóakká váltak-e, illetve van-e különbség a fluens és nonfluens betegek teljesítményében.

A magnófelvételre a történeten kívül az első és utolsó alkalommal a vizsgálatvezetővel folytatott hétköznapi témát érintő dialógus is fölkerült. Az afázia-diagnózisokat a WAB-eredmények alapján állítottuk föl. Az állapotváltozás indikátoraként épp így az első és utolsó alkalommal fölvettük a H-T-P tesztet is. A betegek adatait az 1. táblázat mutatja.

1. táblázat. A vizsgálatban részt vevő betegek adatai

\begin{tabular}{|l|l|l|l|l|c|}
\cline { 2 - 6 } \multicolumn{1}{l|}{} & \multicolumn{1}{c|}{ Név } & Életkor & \multicolumn{1}{c|}{ Végzettség } & \multicolumn{1}{c|}{ Afázia típusa } & WAB AQ \\
\hline 1. & S. F. & 77 év & egyetem & vezetéses & 84,6 \\
\hline 2. & N. B. & 70 év & érettségi & Wernicke & 55,8 \\
\hline 3. & H. M. & 44 év & 8 általános + ip. & transzkort. motoros & 66 \\
\hline 4. & K. B. & 60 év & 8 általános + ip. & Wernicke & 59 \\
\hline 5. & R. O-né & 71 év & 8 általános & Wernicke & 40,6 \\
\hline 6. & T. M. & 67 év & 8 általános + ip. & vezetéses & 76 \\
\hline 7. & D. I-né & 68 év & föiskola & Wernicke & 36,6 \\
\hline 8. & Sz. V. & 42 év & egyetem & Broca & 44 \\
\hline 9. & B. G-né & 63 év & érettségi & vezetéses & 78 \\
\hline
\end{tabular}

\section{EREDMÉNYEK}

A 9 főből az első alkalommal mindegyik azzal a meggyőződéssel kezdett az elmondáshoz, hogy nem fog tudni eleget tenni a feladatnak. A betegek fölvételei arról tanúskodnak, hogy valamennyiük számára az a saját aktivitás, amelyet az 5 alkalommal önállóan összeállított mese megkonstruálása jelentett, a beszédfunkciókban - a zavar jellegétől függetlenül - javulást eredményezett. Kereső stratégiákat mozgósított, a rendelkezésre álló, változó eredetű információ földolgozásának különböző eszközeit kínálta, s ezek azonnal kontrollálhatóak is voltak. Az afáziatípusoknak megfelelően különbözött egymástól a mesefeldolgozások alakulása. Az igazán fontos információ azonban inkább az volt, hogy a betegek a feladat nyújtotta lehetőségekkel viszonylag hamar és könnyen éltek, a beszédprodukció javulása a gyakorló logopédusok számára is meglepően gyors volt. 
A három vezetéses afáziás beteg kezdeti magnófelvételei arról tanúskodnak, hogy jelentős időt fordítanak a helyes szó megtalálására, újból és újból nekifutnak, érzékelvén, hogy még mindig nem sikerült jól kimondaniuk, amit szerettek volna. Sok üresjárat, ismételgetés, elakadás, illetve a keresés föladása található az első, történetté nem igazán szerveződő mesékben. A záró felvételeken pedig már észlelhető, hogy nem ragadnak le egy-egy szó helyes kimondásánál, az egyeztetési problémáknál, hanem a mese egészét törekednek visszaadni, mondanivalójuk jelentésére koncentrálnak, s ezzel az adekvát szóhasználat és mondatszerkezet fölbukkanásának esélye is nagyobb.

Négy betegnél Wernicke afázia volt diagnosztizálható a Western szerint. A bőven folyó, inadekvát beszédben a mese megszabta keretek növelték az odaillő szavak fölbukkanási esélyét. Lehetett ez „kicsi ember” - törpe helyett, vagy „kislány” Hófehérke helyett, illetve a "gonosz" - a mostoha helyett. Az alma, amelynek a Hófehérke történetében különös jelentősége van, vagy az elvesztett cipő Hamupipơke meséjében az emléktárból szinte mindenkinél lehívható volt, s akár gesztus, akár a jelzői szerkezet révén ki is mondták. A szándékok, az indítékok helytálló megnevezése jóval korábban fölbukkant s mintegy ellátta történetükben a nominatív funkciókat. Jellemző volt még, hogy a már egyszer helyesen kimondott név a lexikai tárból jóval könnyebben volt ismételten előhívható a történet folyamatában, s később is. Direkt rákérdezésre azonban a név fölbukkanási esélye az ismétléskor csökkent! (Például: Tehát ki is ez a kislány? - kérdésre nincs válasz, miközben tisztán, többször is az adott kontextusban kimondja, hogy Hamupipőke lábáról leesett a cipő.) Egyetlen betegnél (D. I-né) és éppen az utolsó ülésnél olyan mese került exponálásra, amelyet korábban nem ismert. Történet helyett képleírásokat adott, nem állt össze az események láncolata egységes egésszé. A képek szereplőit ezzel együtt is a korábbinál adekvátabban nevezte meg.

A transzkortikális motoros afáziás beteg első magnófelvétele hosszú szünetekkel tarkított, s minduntalan kifejezést adott annak a meggyőződésének, hogy ez nem fog neki menni. Elégedetlen volt önmagával, nem találta odaillőnek a mobilizált szavakat, helyesbíteni igyekezett, s ez még inkább széttördelte a beszédet. Fokozatosan egyre több mesefordulat „csúszott ki automatikusan” a száján, s igen komoly előkészítő munkát végzett, mielőtt belefogott a történet elmesélésébe. Az utolsó két fölvételen határozottan kimutatható, hogy a történetszövés vége felé mobilizálódnak nagyobb számban a mese elemei, folyamatosabb a beszéd. A többször visszatérő elemek pedig a nominatív funkciókban vontak komoly javulást maguk után.

A Broca afáziás beteg első fölvételei rendkívül töredékesek, a mese töltelékszavai viszont szinte azonnal fölbukkannak. Hic et nunc - jelenetszerűen, érzékletesen mutatja be a képre támaszkodva a szereplők szavait, szinte minimális verbális produkcióval. Durva megtapadások gátolják a történet továbbgördítését, sztereotip szófordulatok tarkítják beszédét. Ahogyan maga a régen ismert közeg elkezd munkálni benne, fokozatosan egyre bővül az adott mese mobilizált elemeinek száma, tér át az elbeszélő stílusra, s nem csak a töltelékek, de a funkcióval rendelkező szavak is adekvátan aktivizálódnak. 
A spontán beszéd változása a magnófelvételek tanúsága szerint párhuzamosnak volt mondható a mesefeldolgozás adataival.

A betegek rajzát elemezve - H-T-P - valamennyi a kezdeti egysíkú, egyszerú, bizonytalan vonalakkal jellemzett rajzhoz képest az ötödik alkalommal biztosabb vonalvezetésű, részletgazdagabb, kidolgozottabb figurákat készít. Érvényes ez akkor is, ha bal kézzel készültek a rajzok.

Összességében tehát az a tapasztalat, amelyet a szövegfeldolgozás révén a beszédfunkciók alakulásában a neuropszichológus vezetésével a beteg megszerez, elsősorban azokat a működő információföldolgozási csatornákat mobilizálja és erősíti meg, amelyeket maga a beteg képes igénybe venni a saját produkciójának értékelése következtében.

Az indirekt eszközökkel elért javuláshoz képest a direkt feladatokban eltérően viselkedtek a fluens és nonfluens betegek. Amíg a fluensek számára az alapos előkészítés, a többszörös használat a megnevezést megkönnyítette, a nonfluens betegeknél maga a megnevezés változatlanul nehezített maradt.

\section{IRODALOM}

BACH-Y-Rita P. (1988) Brain plasitcity. In Goodgold, J. (ed.) Rehabilitation medicine. 113118. Mostby, St. Luis

BACH-Y-RitA, P. (1990) Brain plasticity as a basis for recovery of functions in humans. Neuropsychologia, 6 .

Christensen, A-L., Uzzell, B. P. (1994) Brain Injury and Neuropsychological Rehabilitation, L. Erlbaum Ass. Hillsdale

FREund T. (1999) Magatartás- és memóriazavarokkal kapcsolatos idegrendszeri szerkezetek. Ideggyógyászati Szemle, 5-6, 208-214.

Gummow, L. J., Gregory, V. R., MacNamara, S. E. (1990) Factors Influencing Utilization of Postdiscarge Cognitive Rehabilitation Programs. Health Services Research, 1.

KaPur, N. (1991) Managing your memory. Memory Aids Unit Wessex Neurol Centre, Southampton

KéRI Sz., JANka Z. (1999) A szkizofrénia neurokognitív modellje. Magyar Pszichológiai Szem$l e, 4,591-608$.

Kertesz, A. (1992) Discussion: Treatment of Specific Deficits. In von Steinbüchel, N., von Cramon, D. Y., Pöppel E. (eds) Neuropsychological Rehabilitation. 256-260. Springer Verlag, Berlin-Heidelberg-Budapest

LeZAK, M. D. (1995) Neuropsychological Assessment. 3. ed. Oxford University Press, New York

LuRIJA, A. R. (1975) A neuropszichológia jelentősége a pszichológia és a klinikum számára. In Lurija, A. R. Válogatott tanulmányok. 75-92. Gondolat Könyvkiadó, Budapest

Martin, R., Alberdi, M., Sacho Reiger, J. (1993) Treatment of Vascular Dementia. In Culebras, A., Matias Guiu, J., Román, G. (eds) New Concepts in Vasc. Dementia. 123-130. Prous, Barcelona

McGlynn, S. (1990) Behavioral Approaches to Neuropsychological Rehabilitation. Psychological Bulletin, 3. 
NewCOmbe, F. (1985) Rehablitation in clinical neurology: neuropsychological aspects. In Vinken, P. J., Bruyn, G. W., Klawans, H. L. (eds) Handbook of clinical neurology 46. Neurobehavioral disorders. 609-642. Elsevier, Amsterdam

PATAKY I. (1998) Neuropszichológiai rehabilitáció a pszichiátriában - kognitív rehabilitáció. In Füredi J. (szerk.) A pszichiátria magyar kézikönyve. 661-668. Medicina Könyvkiadó, Budapest

PUHR, U. (1999) Theoretical background and effectiveness of RehaCom - a computer-aided cognitive rehabilitation package. Abstract in Conference of the Central and Easter European Stroke Society, Budapest

The road ahead (1992) - A Stroke Recovery Guide Nat. Stroke Association, 2. ed.

WAHrborG, P. (1988) After stroke. University of Göteborg, Göteborg

Wesnes, K. A., Hildebrand, K., Mohr, E. (1999) Computerised cognitive assessment. In Wilcock, G. W., Bucks, R. S., Rockwood, K. (eds) Diagnosis and management of dementia. A manual for memory disorders teams. 124-136. Oxford University Press, Oxford

\title{
STORY TELLING - A POSSIBLE NEW NEUROPSYCHOLOGICAL INTERVENTION
}

\author{
PATAKY, ILONA
}

The study presents a practical guide for clinical neuropsychologists working at neurological units. The neuropsychological assessment of cognitive functions of organic brain damaged patients has a therapeutical point of view for the medical and the psychological, psychoterapeutical tradition, as well. We presented well-known tales on colorful pictures to activate verbal processes of 9 right handed poststroke aphasic patients (6 males, 3 females - 7 fluents and 2 nonfluents). Each patients took part on 5 sessions of story telling. The aphasia classification was made by the Hungarian Version of the Western Aphasia Battery. The patients'verbal performances were tape-recorded, later transcribed and analyzed. The therapeutic situation gave the opportunity for aphasics to select among the different types of information and for the neuropsychologist to detect what kind of coping strategies were used or preferred by the patients.

Key words: cognitive mapping, -therapy, -style, -rehabilitation, releasing, inhibiting, transfer, skills-technics, coping strategy 